\title{
ZWIĄZEK MIĘDZY EFEKTYWNOŚCIĄ I RENTOWNOŚCIĄ BANKÓW KOMERCYJNYCH W POLSCE
}

\section{WPROWADZENIE}

Zapoczątkowany w 1989 r. okres przeobrażeń strukturalnych w polskim systemie gospodarczym wiązał się $\mathrm{z}$ przeprowadzeniem reformy systemu bankowego. Proces przemian majacy na celu przekształcenie systemu bankowego z postaci monobanku właściwego dla gospodarki nakazowo-rozdzielczej w system dwuszczeblowy konieczny do funkcjonowania gospodarki rynkowej rozpoczął się wraz z uchwaleniem przez Sejm w styczniu tego samego roku ustawy - Prawo bankowe oraz ustawy o Narodowym Banku Polskim, wyznaczających ramy prawne działalności bankowej. Pierwszym wyraźnym krokiem demonopolizacji było wyodrębnienie z dniem 1 lutego 1989 r. ze struktur Narodowego Banku Polskiego działających w najważniejszych ośrodkach gospodarczych kraju - dziewięciu regionalnych banków komercyjnych, które przejęły od banku centralnego uprawnienia w zakresie działalności kredytowej i depozytowej dla sektora pozabankowego.

Zachodzące w kolejnych etapach przemiany związane z restrukturyzacja, prywatyzacją i konsolidacja, prowadzace do wzrostu konkurencji w polskim sektorze bankowym powinny również służyć poprawie efektywności działających w nim banków, co stanowiło przesłankę podjęcia bardzo ważnego i interesującego problemu badawczego: oceny efektywności polskiego sektora bankowego oraz potencjalnego związku pomiędzy rentownością a efektywnościa działających na terenie Polski banków komercyjnych w latach 2000-2012.

\section{MIEJSCE WSKAŹNIKÓW RENTOWNOŚCI W ANALIZIE DZIAŁALNOŚCI BANKU}

Zdaniem Petera S. Rose'a efektywność jest wskaźnikiem obrazującym, w jakiej mierze zarząd i personel banku były w stanie utrzymać tempo wzrostu jego przychodów i dochodu na poziomie wyższym niż tempo wzrostu jego kosztów operacyjnych ${ }^{1}$. Podstawową ocenę efektywności działalności banków

${ }^{1}$ P. S. Rose, Zarzadzanie bankiem komercyjnym. Wytwarzanie $i$ sprzedaż ustug finansowych, t. 1, tłum. P. Kuropatwiński, ZBP, Warszawa 1997, s. 418. 
można uzyskać w wyniku przeprowadzenia analizy wskaźnikowej, w której dość dużą grupę stanowią wskaźniki efektywności. Spośród nich najpowszechniej wykorzystywane są wskaźniki rentowności, a zwłaszcza:

a) wskaźnik ROA (return on assets - zwrot na aktywach, obliczany jako stosunek wyniku finansowego do aktywów ogółem),

b) wskaźnik ROE (return on equity - zwrot na kapitale, wyznaczany jako stosunek wyniku finansowego do kapitałów własnych),

które można szacować w odniesieniu do wyniku finansowego brutto oraz netto.

Wskaźnik ROE szacuje stopę zwrotu osiaganą przez akcjonariuszy, korzyści otrzymywane przez akcjonariuszy w wyniku zainwestowania kapitału. ROA natomiast ocenia umiejętności zarządu banku w odniesieniu do gospodarowania majątkiem, wykorzystania aktywów do wypracowania odpowiedniego wyniku².

Równość między wartościami wskaźników ROA i ROE możliwa jest w sytuacji finansowania aktywów banku wyłącznie kapitałami własnymi. Jest to jednak raczej sytuacja wyłącznie teoretyczna, poniewaź źródłem pokrycia majątku banku są oprócz kapitałów własnych również kapitały obce (przede wszystkim zobowiązania wobec klientów i instytucji finansowych oraz zobowiązania związane z emisją własnych papierów dłużnych) ${ }^{3}$.

Zależność występujacca pomiędzy wskaźnikami ROA i ROE można przedstawić w formie równania (1), wykorzystując do tego celu pojęcie dźwigni finansowej (korzyść uzyskiwaną w wyniku efektywnego wykorzystania kapitałów obcych $)^{4}$.

$$
R O E^{5}=R O A * E M .
$$

Wartość EM (equity multiplier) w równaniu (1) to mnożnik dźwigni finansowej określajacy efektywność zarządzania kapitałem własnym, obliczany według następującej formuły ${ }^{6}$ :

$$
E M=\frac{R O E}{R O A}=\frac{\text { aktywa }}{\text { kapitat wtasny }} .
$$

Wskutek zwiększania wartości mnożnika EM, czyli stosowania dźwigni finansowej, bank może doprowadzić do wzrostu stopy zwrotu z kapitału (ROE) w odniesieniu do danej wartości wskaźnika ROA. Możliwe są następujące relacje pomiędzy wartościami $\mathrm{ROA}$ i $\mathrm{ROE}^{7}$ :

- ROE > ROA - (pożądana przez bank sytuacja) występowanie dźwigni finansowej w sytuacji efektywnego wykorzystania kapitałów własnych,

${ }^{2}$ P. S. Rose, op. cit., s. 150 i 152.

${ }^{3}$ A. Gospodarowicz (red.), Analiza i ocena banków oraz ich oddziałów, Wyd. Akademii Ekonomicznej im. Oskara Langego we Wrocławiu, Wrocław 2002, s. 13.

${ }^{4}$ Ibidem, s. 13.

${ }^{5}$ Ibidem.

${ }^{6}$ Ibidem

${ }^{7}$ Ibidem, s. 14. 
- $\mathrm{ROE}=\mathrm{ROA}-$ finansowanie aktywów w całości przez kapitał własny,

- ROE < ROA - (sytuacja negatywna) koszt pozyskania kapitałów obcych przewyższa zyski związane $\mathrm{z}$ ich wykorzystaniem, sytuacja taka obniża zyskowność kapitałów własnych i informuje o niedostatecznej efektywności działania banku.

Przedstawioną w równaniu (1) zależność między wskaźnikami ROA i ROE można zaprezentować w szerszej postaci, wykorzystując do tego dwa nowe pojęcia - marża zysku ( $P M$ - profit margin, stosunek wyniku finansowego do przychodów operacyjnych z wyłączeniem rozwiązania rezerw i zysków nadzwyczajnych) oraz wskaźnik wykorzystania aktywów (AU - assets utilization, stosunek przychodów operacyjnych z wyłączeniem rezerw i zysków nadzwyczajnych do aktywów) ${ }^{8}$. Przy ich wykorzystaniu zależność z równania (1) przedstawia się następująco ${ }^{9}$ :

$$
R O E=R O A * E M=P M * A U * E M .
$$

Z otrzymanego równania (3) wywnioskować można, że istnieje możliwość zapisu wskaźnika ROA w postaci następującego iloczynu:

$$
R O A=P M * A U
$$

Równania (1) i (3) stanowią I i II etap dekompozycji wskaźników efektywności zwanej piramidą Du Ponta. Kolejne kroki tworzyć można wskutek rozkładu marży zysku i wskaźnika wykorzystania aktywów na ich składowe.

\section{MODELE NIEPARAMETRYCZNEJ METODY DEA I MOŻLIWOŚĆ ICH ZASTOSOWANIA DO OCENY EFEKTYWNOŚCI BANKU}

Przedstawione w punkcie II wskaźniki rentowności zawężają ocenę efektywności banku tylko do obszaru finansowego. Jak się jednak okazuje, ocena efektywności instytucji finansowej, jaką jest bank, może być prowadzona również w aspekcie organizacyjnym i kosztowym ${ }^{10}$.

Efektywność organizacyjną (określaną również mianem skuteczności lub konkurencyjności) można rozumieć jako identyfikację czynników rozstrzygających o tym, że dany bank jest lepszy od innych (tzw. czynniki sukcesu) ${ }^{11}$.

Badanie efektywności kosztowej traktować można jako określenie, czy uzyskana wielkość produkcji została osiagnięta przy właściwej skali oraz

${ }^{8}$ M. Iwanicz-Drozdowska, Metody oceny działalności banku, Poltext, Warszawa 1999, s. 82.

${ }^{9}$ Ibidem.

${ }^{10}$ M. Capiga, Efektywność jako kryterium oceny banku, „Miesięcznik Finansowy Bank” 2002, nr 3 (1114), s. 48.

${ }^{11}$ G. Rogowski, Metody analizy i oceny działalności banku na potrzeby zarzadzania strategicznego, Wyd. WSB, Poznań 1998, s. 55. 
strukturze nakładów. Nieefektywność kosztowa występuje w sytuacji, w której podmiot ponosi koszt większy, niż wskazuje graniczna funkcja kosztu ${ }^{12}$. W literaturze poświęconej badaniu efektywności banków można spotkać także podejście rozpatrujące efektywność kosztową w kontekście odpowiedzi na pytanie, jak bank zarządza własnymi kosztami w porównaniu z bankami funkcjonujacymi w podobnych warunkach ${ }^{13}$.

Jedną z metod umożliwiających ocenę efektywności banku w wielu obszarach jego działalności jest metoda nieparametryczna Data Envelopment Analysis (DEA). Na jej podstawie dokonuje się oceny efektywności technicznej banków, czyli relacji pomiędzy ich produktywnością (stosunkiem otrzymanego efektu do poniesionego nakładu ${ }^{14}$ ) a maksymalną produktywnością która można uzyskać w warunkach obowiąujaccej technologii.

W przypadku szacowania efektywności banków sedno metody DEA można w skrócie przedstawić jako ${ }^{15}$ :

- wyszukanie najlepszych banków (ze zbioru banków, dla których wyznaczana jest efektywność), które wyznaczają granicę możliwości (obwiednię), a następnie

- oszacowanie odległości (w przestrzeni współrzędnych), jaka dzieli pozostałe analizowane pod kątem efektywności banki od wyznaczonej granicy możliwości.

DEA nazywana jest metodą granicznej analizy danych. Podmiotami tej analizy sa tzw. jednostki decyzyjne (DMU - decision making units) ${ }^{16}$. Wzorcowe wartości efektywności technicznej ${ }^{17}$ wyznaczane sa na podstawie kombinacji najlepszych wyników jednostek z danej grupy badawczej. Na podstawie osiagnięć obiektów objętych analizą tworzona jest krzywa efektywności (graniczna funkcja produkcji stanowiąca empiryczną obwiednię danych ${ }^{18}$ ), na której znajdują się obiekty efektywne (o efektywności równej jeden) ${ }^{19}$.

12 J. Marzec, Produkty, czynniki produkcji i funkcja kosztów w badaniach efektywności kosztowej banków, „Ekonomista” 1999, nr 3, s. 283-284.

13 T. P. Opiela [kier. nauk.], Efektywność i ryzyko sektora bankowego $w$ Polsce, „Materiały i Studia NBP” grudzień 1999, z. 96, s. 16-17.

${ }_{14}$ M. Kisielewska, Ocena efektywności banków $i$ ich oddziałów metoda Data Envelopment Analysis - wybrane zagadnienia metodologiczne, w: D. Zarzecki (red.), Zarzadzanie finansami. Inwestycje $i$ wycena przedsiębiorstw , t. 1, Fundacja na Rzecz Uniwersytetu Szczecińskiego, Szczecin 2006, s. 515 .

15 M. Zaleska (red.), Wspótczesna bankowość, t. 1, Difin, Warszawa 2007, s. 615-616.

${ }_{16}$ M. Gospodarowicz, Procedury analizy i oceny banków, „Materiały i Studia NBP” czerwiec 2000, nr 103, s. 27.

17 Efektywność wyznaczana za pomocą metody DEA nazywana jest także efektywnością technologiczna. Por. np. B. Guzik, Podstawowe modele DEA w badaniu efektywności gospodarczej i społecznej, Wyd. UEP, Poznań 2009, s. 22; T. Kopczewski, Efektywność technologiczna i kosztowa banków komercyjnych w Polsce w latach 1997-2000. Część I, „Materiały i Studia NBP” listopad 2000, nr 113; T. Kopczewski, M. Pawłowska, Efektywność technologiczna i kosztowa banków komercyjnych $w$ Polsce $w$ latach 1997-2000. Część II, „Materiały i Studia NBP” grudzień 2001, nr 135 .

18 B. Guzik, op. cit., s. 13-14.

19 Zdarzają się sytuacje, w której obiekt leżący na krzywej efektywności jest nieefektywny, jest to tzw. obiekt graniczny (boundary object) (G. Rogowski, Metody..., op. cit., s. 132). Szerzej na temat tego problemu w: A. Charnes et al., Polyhedral Cone-Ratio DEA Models with an Illustra- 
Wszystkie obiekty leżące poza krzywą efektywności odznaczają się pewnym stopniem nieefektywności, który ma swoje odzwierciedlenie w poziomie efektywności niższym od jedności ${ }^{20}$.

Efektywność szacowaną przy użyciu metody DEA definiuje się następujaco $^{21}$ :

$$
\text { EFEKTYWNOSC }=\frac{\sum_{r=1}^{s} u_{r} E F E K T_{r}}{\sum_{i=1}^{m} v_{i} N A K E A D_{i}},
$$

gdzie: $r=1, \ldots, s ; i=1, \ldots, m ; s$ - liczba efektów, $m$ - liczba nakładów, $u_{r}, v_{i}$ - wagi świadczące o ważności konkretnego efektu/poszczególnych nakładów.

Modele wykorzystywane do obliczenia efektywności metodą DEA mogą być rozpatrywane w dwojaki sposób, jako ${ }^{22}$ :

a) modele zorientowane na nakłady, gdy celem jest minimalizacja nakładów przy jednoczesnym ograniczeniu dolnej wielkości rezultatów, lub

b) modele zorientowane na efekty, gdy celem jest maksymalizacja wyników przy ograniczeniach w stosunku do górnej wielkości nakładów.

Jednym z etapów poprzedzających ocenę efektywności banków metodą DEA jest ustalenie nakładów i wyników ich działalności. Jak się okazuje, nie jest to rzecz prosta, ponieważ istnieje wiele sposobów pomiaru produkcji banku. Można tego dokonać na przykład przez określenie liczby rachunków, średniej wartości rachunku, aktywów na zatrudnionego, średniej liczby pracowników w oddziale, całkowitej wartości depozytów i/lub kredytów, wielkości dochodów odsetkowych i pozaodsetkowych ${ }^{23}$.

Trudności w ocenie efektywności banku sprawia nie tylko fakt, że produkcja banku może być określana przez różne mierniki, lecz także to, że wskazuje się kilka odmiennych ujęć jej pomiaru (odmiennych klasyfikacji nakładów i efektów produkcji) opartych na koncepcjach: pośrednika finansowego, produkcyjnej, zasobów finansowych, kosztu użytkownika oraz wartości dodanej ${ }^{24}$. Głównymi ujęciami technologii bankowej są podejścia produkcyjne oraz

tive Application to Large Commercial Banks, „Journal of Econometrics” 46, 1990, nr 1-2, s. 73-91; L. M. Seiford, R. M. Thrall, Recent Developments in DEA. The Mathematical Programming Approach to Frontier Analysis, „Journal of Econometrics” 46, 1990, nr 1-2, s. 7-38.

${ }^{20}$ E. Mataczyńska, Zarys metody DEA jako narzędzia badania efektywności przedsiębiorstw regulowanych, „Studia Ekonomiczne” 2007, nr 1-2, s. 97-98.

${ }^{21}$ G. Rogowski, Analiza i ocena działalności banków z wykorzystaniem metody DEA, „Bank i Kredyt" 1996, nr 9, s. 42.

22 B. Guzik, op. cit., s. 33.

${ }^{23}$ K. Matthews, J. Thompson, Ekonomika bankowości, tłum. R. Kokoszczyński, PWE, Warszawa 2007, s. 168.

${ }^{24}$ C. A. Favero, L. Papi, Technical Efficiency and Scale Efficiency in the Italian Banking Sector: A Non-parametric Approach, „Applied Economics” 27, 1995, nr 4, s. 388-389. Por. D. C. Wheelock, P. W. Wilson, Evaluating the Efficiency of Commercial Banks: Does Our View of What Banks Do Matter?, „Review of Federal Reserve Bank of St. Louis” 77, July/August 1995, nr 4, s. 40-42. 
pośrednictwa finansowego. W pierwszym z nich czynności bankowe traktowane są jako produkcja usług na rzecz deponentów i kredytobiorców ${ }^{25}$.

Kolejne podejście do klasyfikacji nakładów i efektów działalności banku, czyli podejście od strony pośrednictwa finansowego, opiera się na roli, jaką sprawują banki, pośrednicząc między podmiotami z nadwyżką finansową oraz tymi, które na tę nadwyżkę zgłaszają zapotrzebowanie ${ }^{26}$.

Punktem wyjścia metody DEA jest programowanie liniowe metoda oceny względnej efektywności granicznej jednorodnych jednostek decyzyjnych $^{27}$. Funkcję celu w liniowych modelach DEA stanowi miara efektywności technicznej Debreu-Farrella odpowiednio zorientowana na nakłady lub na efekty ${ }^{28}$.

Pierwotny model DEA został wprowadzony przez autorów samej metody, tj. Abrahama Charnesa, Williama W. Coopera i Edwarda Rhodesa i nazwany od pierwszych liter ich nazwisk modelem CCR ${ }^{29}$. Jeżeli $n$ obiektów wykorzystuje $m$ nakładów do produkcji $s$ efektów i obiekt $O_{o}$ wykorzystuje ilość $x_{i o}$ nakładu $i$ do wytworzenia $y_{r o}$ efektu $r(o=1, \ldots, n$-indeks obiektu, $i=1, \ldots, m$-indeks nakładu, $r=1, \ldots, s$-indeks efektu) funkcja celu modelu CCR przyjmuje postać ${ }^{30}$ :

$$
\max _{u, v} \frac{\sum_{r=1}^{s} u_{r} y_{r o}}{\sum_{i=1}^{m} v_{i} x_{i o}} .
$$

Dzięki zastosowaniu metody transformacji Charnesa-Coopera przedstawiony w postaci nieliniowej model można sprowadzić do postaci liniowej ${ }^{31}$. Najbardziej rozpowszechnioną modyfikację klasycznego modelu CCR stanowi model opracowany przez Rajiva D. Bankera, Abrahama Charnesa oraz Williama W. Coopera i nazwany od pierwszych liter ich nazwisk modelem $\mathrm{BCC}^{32}$, w którym uchylono założenie o stałych efektach skali.

${ }^{25}$ X. Freixas, J.-Ch. Rochet, Mikroekonomia bankowa, tłum. P. Żukowski, A. Balcarek, CeDeWu, Warszawa 2007, s. 120.

${ }^{26}$ Ibidem.

${ }^{27}$ A. Gospodarowicz (red.), op. cit., s. 55.

28 A. Prędki, Analiza efektywności za pomoca metody DEA: Podstawy formalne i ilustracja ekonomiczna, „Przegląd Statystyczny” 2003, nr 1, s. 90.

${ }^{29}$ Por. A. Charnes, W. Cooper, E. Rhodes, Measuring the Efficiency of Decision Making Units, „European Journal of Operational Research” 2, 1978, nr 6, s. 429.

${ }^{30}$ G. Rogowski, Metody..., s. 133-134.

${ }^{31}$ Ibidem, s. 134; M. Pawłowska, Wptyw fuzji i przejęć na efektywność w sektorze banków komercyjnych $w$ Polsce $w$ latach 1997- 2001, „Bank i Kredyt” 2003, nr 2, s. 25.

${ }_{32}$ Por. R. D. Banker, A. Charnes, W. W. Cooper, Some Models for Estimating Technical and Scale Inefficiencies in Data Envelopment Analysis, „Management Science” 30, September 1984, nr 9, s. 1078-1092. 


\section{CHARAKTERYSTYKA PRÓBY BADAWCZEJ ORAZ WIELKOŚCI OKREŚLAJĄCYCH NAKŁADY I EFEKTY BADANYCH BANKÓW}

Aby maksymalnie wydłużyć okres badawczy, zgromadzono dane za lata 2000-2012. Wybór banków objętych badaniem oparto na corocznych rankingach Najlepsze banki „Gazety Bankowej” oraz 50 największych banków w Polsce „Miesięcznika Finansowego Bank”. Biorąc pod uwagę kompletność i porównywalność danych w całym okresie badania wybrano 15 następujących banków:

1. PKO Bank Polski SA

3. Bank Pekao SA

5. ING Bank Śląski SA

7. BRE Bank SA

9. Bank Zachodni WBK SA

11. Bank Handlowy w Warszawie SA

13. Bank Millennium SA

15. Kredyt Bank SA
2. Bank BGŻ SA

4. Raiffeisen Bank Polska SA

6. BNP Paribas Bank Polska SA

8. Bank BPH SA

10. Nordea Bank Polska SA

12. Credit Agricole Bank Polska SA

14. Invest-Bank SA

W poszczególnych latach analizy liczebność badanej zbiorowości banków była stała ${ }^{33}$.

Biorąc pod uwagę koncepcję pośrednika finansowego, przyjęto za Kinga Stępień $^{34}$, w ramach nakładów i efektów charakteryzujących działalność wybranych banków następujące czynniki ${ }^{35}$ :

${ }^{33}$ Bank Millennium - przyjęto dane dla BIG Banku Gdańskiego za rok 2000; BNP Paribas Bank Polska SA - przyjęto dane dla Fortis Banku za lata 2000-2008; Credit Agricole Bank Polska SA - przyjęto dane dla Lukas Banku SA za lata 2000-2010;

${ }^{34}$ K. Stępień, Konsolidacja a efektywność banków w Polsce, CeDeWu, Warszawa 2004, s. 151.

35 Nazewnictwo zgodne z tym, które zaprezentowano w pracy K. Stępień, op. cit., oraz Najlepsze banki 2001. Ranking Gazety Bankowej, „Gazeta Bankowa” 2001, nr 26 (661), s. 30-33; Najlepsze banki 2002. Ranking Gazety Bankowej, „Gazeta Bankowa” 2002, nr 26 (713), s. 30-33; Najlepsze banki 2003. Ranking Gazety Bankowej, „Gazeta Bankowa” 2003, nr 25 (765), s. 50-53; Dodatek Specjalny Najlepsze banki 2006, „Gazeta Bankowa” 2006, nr 26 (922), s. VIII-XI; Najlepsze Banki 2007, „Excludere Magazyn Gazety Bankowej” 2007, nr 5, s. 20-23; Najlepsze banki, najlepsi bankowcy 2008. Ranking Gazety Bankowej, „Gazeta Bankowa” 2008, nr 25 (1025), s. 2427. Zatrudnienie, placówki oraz wielkości bilansowe (majątek trwały, depozyty, kredyty, papiery wartościowe) według stanu na koniec poszczególnych lat analizy. Wyboru mierników określających nakłady i efekty dokonano zgodnie z następującymi przesłankami: 1) majątek trwały - podstawowy miernik zasobów materialnych banku; 2) depozyty - źródło finansowania akcji kredytowej banku; 3) koszty działania banku - wskazują na stopień zachowania dyscypliny kosztowej w banku; 4) zatrudnienie - sposób obsługi, utrzymania relacji z klientem oraz profesjonalizm personelu to niejednokrotnie czynniki przewagi konkurencyjnej banku; 5) kredyty - działalność kredytowa jest jedną z podstawowych działalności banków komercyjnych, zakres tej działalności oraz jakość portfela kredytowego przekładają się bezpośrednio na wyniki finansowe banku; 6) papiery wartościowe - transakcje i inwestycje regulujące płynność płatniczą banku; 7) wynik 
1) nakłady:

- majątek trwały - rzeczowe aktywa trwałe,

- depozyty - suma zobowiązań wobec sektora finansowego, niefinansowego oraz budżetowego,

- koszty działania banku - koszty osobowe oraz inne koszty eksploatacyjne, w tym wynajem pomieszczeń, zakup materiałów biurowych oraz innych rzeczy koniecznych do funkcjonowania banku,

- zatrudnienie - liczba etatów w banku,

2) efekty:

- kredyty - suma należności od sektora finansowego, niefinansowego i budżetowego,

- papiery wartościowe - suma takich pozycji sprawozdania finansowego, jak: kasa, operacje z bankiem centralnym, dłużne papiery wartościowe uprawnione do redyskontowania w banku centralnym, należności z tytułu zakupionych papierów wartościowych z otrzymanym przyrzeczeniem odkupu, dłużne papiery wartościowe, udziały lub akcje w jednostkach zależnych, udziały lub akcje w jednostkach współzależnych, udziały lub akcje w jednostkach stowarzyszonych, udziały lub akcje w innych jednostkach, pozostałe papiery wartościowe i inne aktywa finansowe, - wynik z tytułu prowizji - nadwyżka prowizji otrzymanych nad zapłaconymi (ujęcie memoriałowe, pozycja z rachunku zysków i strat), - placówki - liczba placówek banku.

Biorąc pod uwagę opisane w punkcie II wskaźniki ROA i ROE, wśród badanych banków wyróżniono banki rentowne i nierentowne. Zgodnie z teorią zaprezentowaną w pracach Włodzimierza Wasowskiego oraz Adama Kopińskiego za rentowne uznano banki, dla których wskaźnik ROA przyją wartość wyższa niż 1\%. W przeciwnym razie bank uznano za nierentowny ${ }^{36}$. W odniesieniu do wskaźnika ROE za rentowne uznano banki o wartości wskaźnika większej niż 13\% w danym roku, nierentownymi zaś te, dla których stopa zwrotu z kapitału była niższa od tej wartości bądź jej równa. Przynależność badanych banków do odpowiednich grup w kolejnych latach analizy zaprezentowano w tabelach 1 i 2 .

z tytułu prowizji - wskazuje na poziom zaangażowania banku m.in. w obsługę dużych transakcji finansowania przedsiębiorstw, im większy limit kredytu lub jego wykorzystanie czy też im wyższa udzielona gwarancja bankowa, tym wyższy poziom uzyskanej prowizji przez bank; 8) placówki czynnik odzwierciedlający działanie banku w zakresie rozwoju sieci i zwiększenia skali działania im większa liczba placówek tym większe szanse na wzrost efektywności skali działania banku.

${ }^{36}$ W. Wassowski, Ekonomika i finanse banku komercyjnego, Difin, Warszawa 2004, s. 286; A. Kopiński, Analiza finansowa banku, PWE, Warszawa 2008, s. 154. W przypadku wskaźnika ROE wartość graniczna przyjęto zgodnie z koncepcja przedstawioną w prezentacji Bankowego Funduszu Gwarancyjnego „Jak ocenić bank?” - wskaźniki finansowe z obszaru efektywności można ocenić, porównując ich wielkość do podawanych w opracowaniach BFG i KNF średnich wielkości w sektorze banków komercyjnych. W badanym okresie, tj. w latach 2000-2012, średnia wartość wskaźnika ROE dla banków komercyjnych działających w Polsce wyniosła 13,17\% (ROA 1,21\%). Podobnie jak w przypadku wielkości nakładów i efektów banków objętych badaniem wartości potrzebne do oszacowania wskaźników rentowności podmiotów wchodzących w skład próby badawczej zaczerpnięto z rankingów Najlepsze banki „Gazety Bankowej” oraz 50 największych banków w Polsce „Miesięcznika Finansowego Bank”. 

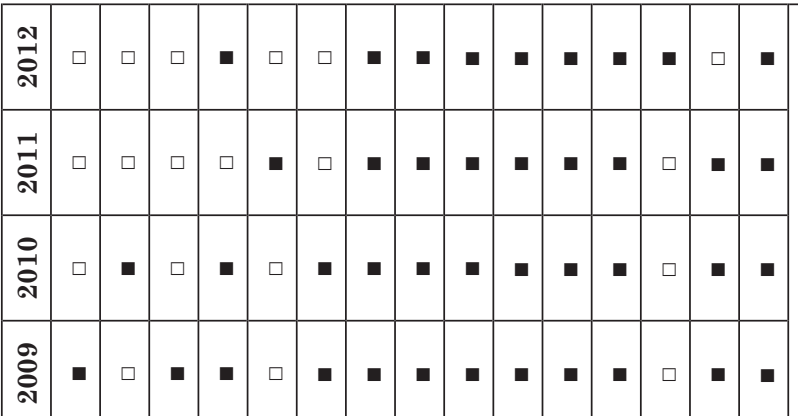

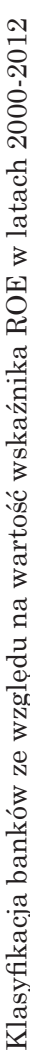

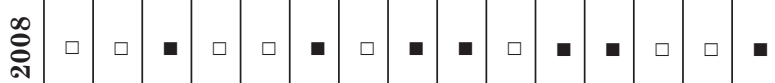

今ั

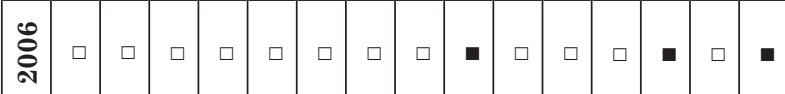

苍

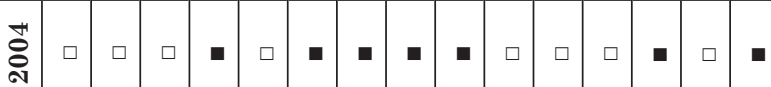
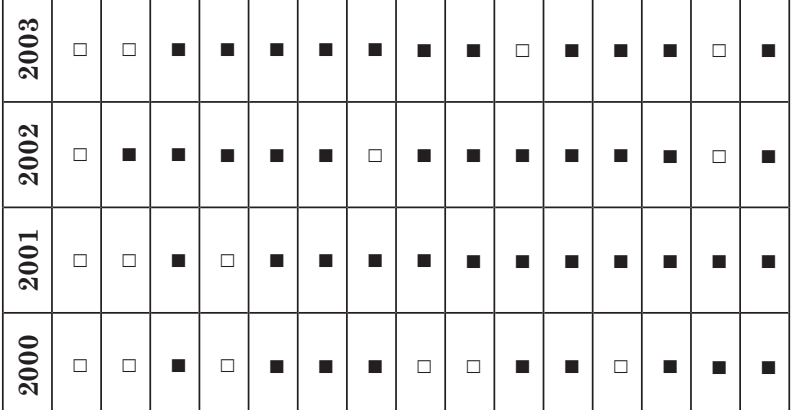

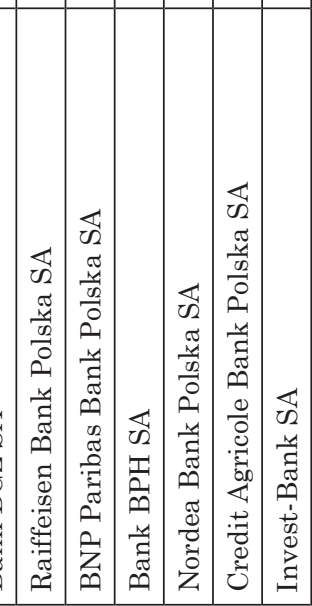

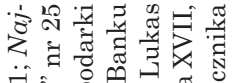

जิ

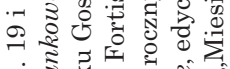

,

$\therefore$ จ

ช.

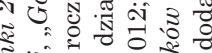

ปั

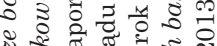

级

20.

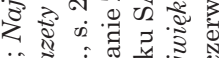

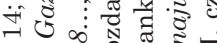

-108 की

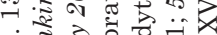

क ₹

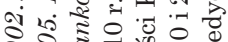

จำ

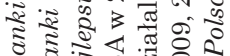

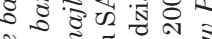

Non

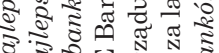

$\sum: \overbrace{}^{\circ}$ 됭

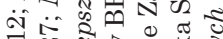

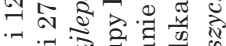

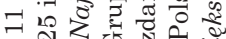

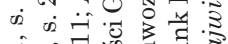

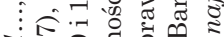

₹ क्ष का का की की

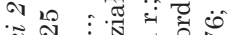

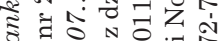

D.

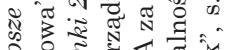

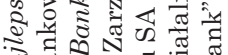

$8 \pi$.

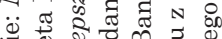

过政

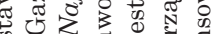

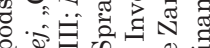

Q.

ฮ व

¿

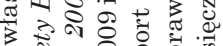

๙

द्य ठ ठ क

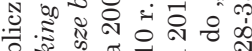

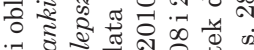

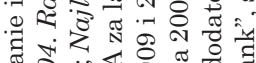

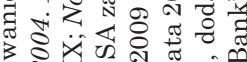

จิ

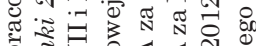

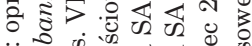

ô. की 


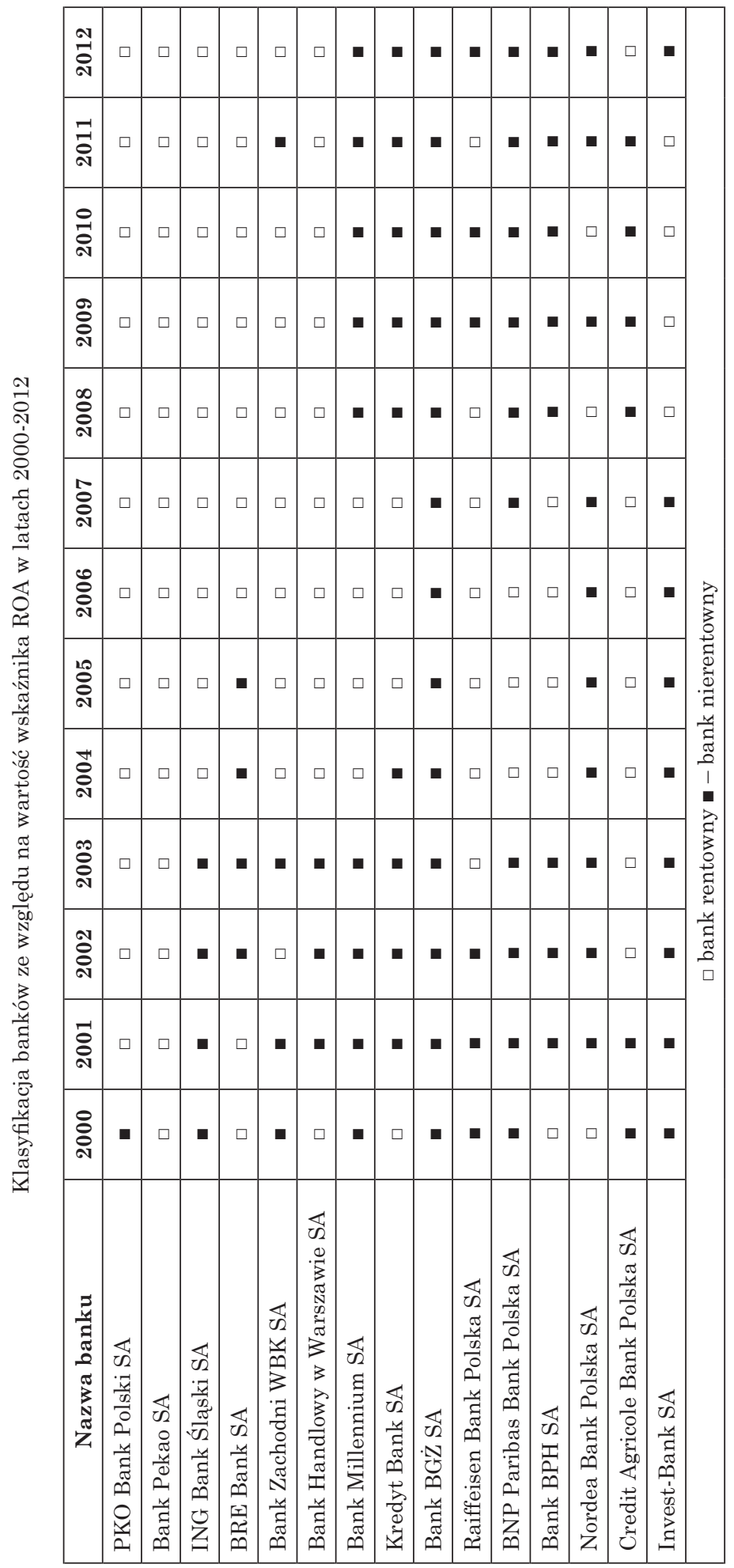

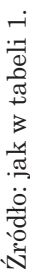


Analiza danych zestawionych w tabelach 1 i 2 pozwala zaobserwować, że aktywa rozpatrywanych banków $\mathrm{w}$ analizowanym okresie charakteryzowały się większą zdolnością do generowania zysku niż kapitały własne. Świadczy o tym mniejsza przewaga liczby banków nierentownych nad rentownymi w przypadku klasyfikacji przeprowadzonej na podstawie wskaźnika ROA niż ROE. Wynika z tego, że analizowane banki w okresie objętym badaniem cechowały się wyższą zdolnością do stawienia czoła rosnącej konkurencji w ramach sektora bankowego niż do ochrony realnej wartości kapitału.

\section{POZIOM MIAR EFEKTYWNOŚCI TECHNICZNEJ NA TLE RENTOWNOŚCI BANKÓW OBJĘTYCH BADANIEM}

W efekcie przeprowadzonej kolejno dla poszczególnych lat 2000-2012 analizy efektywności metodą DEA uzyskano wielkości miar efektywności technicznej badanych banków zestawione w tabeli 3 .

Spośród 15 analizowanych banków 4 okazały się efektywnymi z uwagi na całkowitą efektywność techniczną we wszystkich badanych latach. Były to: BRE Bank SA, Bank Handlowy w Warszawie SA, Credit Agricole Bank Polska SA i Invest-Bank SA. Stabilnymi bankami okazały się BNP Paribas Bank Polska SA oraz Nordea Bank Polska SA, które wyłącznie w jednym roku (odpowiednio 2012 i 2001 r.) wykazały nieznaczny stopień nieefektywności (współczynnik efektywności równy 0,975 - BNP Paribas Bank Polska SA i 0,949 - Nordea Bank Polska SA). Słabsze wyniki efektywności zauważyć można w przypadku Banku BGŻ SA, dla którego efektywność na poziomie 1 odnotowano wyłącznie w 2000 i 2001 r.

Uzyskane poziomy efektywności technicznej przeanalizowano w kontekście rentowności banków mierzonej przedstawionymi wcześniej wskaźnikami ROA i ROE. Biorąc pod uwagę klasyfikację banków zaprezentowaną w punkcie IV, można zauważyć, że w latach słabszych wyników finansowych polskiego sektora bankowego przeważająca grupę stanowiły banki nierentowne ze względu zarówno na wartość wskaźnika ROE, jak i ROA.

Za pomocą metody korelacji liniowej oszacowano siłę zależności pomiędzy efektywnością techniczną banków wchodzących w skład próby badawczej a ich poziomem rentowności mierzonym wartością wskaźników ROE i ROA oraz określono istotność tej zależności. W tym celu obliczono współczynniki korelacji liniowej Pearsona dla średnich miar efektywności technicznej oraz średnich wartości wskaźników rentowności wyliczonych dla każdego banku z próby badawczej za lata 2000-2012, a następnie przeprowadzono dla nich testy istotności.

W wyniku dokonanych wyliczeń oraz procedur testowych uzyskano następujące informacje:

- w przypadku oceny zależności pomiędzy wartością wskaźnika ROE a miara efektywności ecrs współczynnik korelacji liniowej Pearsona równy 0,12 świadczący o bardzo słabej zależności dodatniej między rozpatrywanymi cechami oraz wynik testu istotności współczynnika korelacji, zgodnie z którym nie ma podstaw do odrzucenia hipotezy zerowej o braku zależności między analizowanymi cechami banków ( $p$-wartość $=0,68$; 


\begin{tabular}{|c|c|c|c|c|c|c|c|c|c|c|c|c|c|c|c|c|}
\hline 골 & $\begin{array}{l}8 \\
8 \\
- \\
-\end{array}$ & $\begin{array}{l}8 \\
8 \\
- \\
-1\end{array}$ & \begin{tabular}{l}
$\infty$ \\
\multirow{2}{*}{} \\
$\sigma$ \\
0
\end{tabular} & $\begin{array}{l}8 \\
8 \\
-1\end{array}$ & $\stackrel{8}{8}$ & \& & $\begin{array}{l}8 \\
8 \\
-i\end{array}$ & $\underset{-}{8}$ & $\begin{array}{l}\text { f } \\
\text { 今. } \\
0\end{array}$ & 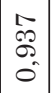 & \begin{tabular}{|c|}
10 \\
5 \\
0 \\
0 \\
0
\end{tabular} & $\begin{array}{l}8 \\
8 \\
-1\end{array}$ & $\begin{array}{l}8 \\
8 \\
-1\end{array}$ & $\left|\begin{array}{l}8 \\
8 \\
0 \\
-i\end{array}\right|$ & 8 & के \\
\hline$\overline{\bar{\nu}}$ & $\underset{-}{8}$ & $\begin{array}{l}8 \\
8 \\
-1\end{array}$ & $\begin{array}{l}8 \\
\vdots \\
-\end{array}$ & $\begin{array}{l}8 \\
8 \\
-1\end{array}$ & $\underset{-1}{8}$ & 8 & $\mid \begin{array}{l}8 \\
8 \\
-1\end{array}$ & $\begin{array}{l}8 \\
8 \\
-1\end{array}$ & $\begin{array}{l}\stackrel{8}{0} \\
\mathscr{8} \\
0\end{array}$ & $\begin{array}{l}8 \\
8 \\
-1\end{array}$ & $\mid \begin{array}{l}8 \\
8 \\
-1\end{array}$ & $\mid \begin{array}{l}8 \\
8 \\
-1\end{array}$ & $\begin{array}{l}8 \\
\delta \\
-1\end{array}$ & $\left|\begin{array}{l}0 \\
8 \\
-1\end{array}\right|$ & 8 & $\hat{\hat{\sigma}}$ \\
\hline 를 & $\underset{-}{8}$ & $\begin{array}{l}8 \\
\& \\
-i\end{array}$ & $\begin{array}{l}8 \\
8 \\
-1\end{array}$ & $\begin{array}{l}8 \\
8 \\
-1\end{array}$ & $\begin{array}{l}8 \\
8 \\
-1\end{array}$ & $\underset{-1}{8}$ & $\mid \begin{array}{l}0 \\
\vdots \\
-1\end{array}$ & $\begin{array}{l}8 \\
8 \\
-1\end{array}$ & $\begin{array}{l}\vec{D} \\
\stackrel{0}{1} \\
0\end{array}$ & $\mid \begin{array}{l}8 \\
8 \\
-1\end{array}$ & $\mid \begin{array}{l}8 \\
8 \\
-i\end{array}$ & $\begin{array}{l}8 \\
\& \\
-1\end{array}$ & $\begin{array}{l}8 \\
\delta \\
-i\end{array}$ & $\left|\begin{array}{l}0 \\
\vdots \\
-i\end{array}\right|$ & : & $\stackrel{\circ}{\circ}$ \\
\hline ڤેे & $\begin{array}{l}\stackrel{2}{\infty} \\
\infty \\
0 \\
0\end{array}$ & $\begin{array}{l}\mathscr{\mathscr { S }} \\
\stackrel{2}{\circ} \\
0\end{array}$ & $\begin{array}{l}8 \\
8 \\
-1\end{array}$ & $\begin{array}{l}8 \\
8 \\
-1\end{array}$ & $\underset{-1}{8}$ & $\underset{-1}{8}$ & $\mid \begin{array}{l}8 \\
8 \\
-i\end{array}$ & $\begin{array}{l}8 \\
8 \\
-1\end{array}$ & $\begin{array}{l}\mathscr{0} \\
\stackrel{0}{0} \\
0\end{array}$ & $\mid \begin{array}{c}8 \\
8 \\
-1\end{array}$ & $\mid \begin{array}{l}8 \\
\vdots \\
-i\end{array}$ & $\begin{array}{l}8 \\
\& \\
-1\end{array}$ & $\begin{array}{l}8 \\
8 \\
-1\end{array}$ & $\left|\begin{array}{l}8 \\
8 \\
-i\end{array}\right|$ & 8 & $\hat{\Omega}$ \\
\hline 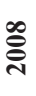 & $\begin{array}{c}\stackrel{H}{N} \\
\infty \\
0 \\
0\end{array}$ & $\begin{array}{l}\infty \\
\stackrel{2}{\circ} \\
\stackrel{5}{0}\end{array}$ & $\begin{array}{l}8 \\
8 \\
- \\
-1\end{array}$ & $\begin{array}{l}8 \\
8 \\
-1\end{array}$ & $\underset{-1}{8}$ & $\stackrel{8}{8}$ & $\begin{array}{l}8 \\
8 \\
-1\end{array}$ & $\underset{-}{8}$ & $\begin{array}{l}0 \\
\stackrel{0}{0} \\
0 \\
0\end{array}$ & $\begin{array}{l}8 \\
\vdots \\
-1 \\
-1\end{array}$ & $\begin{array}{l}8 \\
8 \\
-i\end{array}$ & $\begin{array}{l}8 \\
8 \\
- \\
-1\end{array}$ & $\begin{array}{l}8 \\
\vdots \\
-i\end{array}$ & $\left|\begin{array}{l}8 \\
8 \\
-i\end{array}\right|$ & $\stackrel{8}{8}$ & ह̂. \\
\hline ڤ્ڤે & $\begin{array}{l}8 \\
8 \\
-i\end{array}$ & $\begin{array}{l}8 \\
\& \\
-i\end{array}$ & $\begin{array}{l}8 \\
8 \\
-i\end{array}$ & $\begin{array}{l}8 \\
8 \\
-1 \\
-1\end{array}$ & 8 & $\begin{array}{l}8 \\
0 \\
-1\end{array}$ & $\begin{array}{c}8 \\
8 \\
-i\end{array}$ & $\begin{array}{l}\vec{z} \\
\sigma \\
0\end{array}$ & $\begin{array}{l}\overrightarrow{0} \\
\mathscr{0} \\
8 \\
0\end{array}$ & $\mid \begin{array}{c}8 \\
8 \\
-1 \\
-1\end{array}$ & $\mid \begin{array}{c}8 \\
8 \\
-i\end{array}$ & $\mid \begin{array}{l}8 \\
0 \\
0 \\
-1\end{array}$ & $\begin{array}{l}8 \\
\vdots \\
-1 \\
-1\end{array}$ & $\left|\begin{array}{c}8 \\
\vdots \\
-1 \\
-1\end{array}\right|$ & : & 亏ू. \\
\hline ڤั̀ें & $\underset{-}{8}$ & $\begin{array}{l}8 \\
\& \\
- \\
-1\end{array}$ & $\begin{array}{l}8 \\
8 \\
- \\
-1\end{array}$ & $\begin{array}{l}8 \\
\& \\
-1\end{array}$ & $\underset{8}{8}$ & \& & $\left|\begin{array}{l}8 \\
8 \\
-i\end{array}\right|$ & \begin{tabular}{l}
0 \\
\multirow{2}{*}{} \\
0 \\
0 \\
0
\end{tabular} & $\begin{array}{l}5 \\
5 \\
\infty \\
0 \\
0\end{array}$ & $\begin{array}{l}8 \\
8 \\
-1\end{array}$ & $\begin{array}{l}8 \\
8 \\
-i\end{array}$ & $\begin{array}{l}8 \\
\vdots \\
-1\end{array}$ & $\mid \begin{array}{l}8 \\
8 \\
-i\end{array}$ & $\left|\begin{array}{l}8 \\
8 \\
-i\end{array}\right|$ & 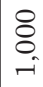 & ڤू. \\
\hline ֻે̊ิ & $\begin{array}{l}\infty \\
\infty \\
\infty \\
\infty \\
0\end{array}$ & $\begin{array}{l}8 \\
8 \\
- \\
-1\end{array}$ & $\begin{array}{l}8 \\
8 \\
-i\end{array}$ & $\begin{array}{l}8 \\
8 \\
-1\end{array}$ & $\stackrel{8}{8}$ & $\stackrel{8}{8}$ & $\begin{array}{l}8 \\
\& \\
-i\end{array}$ & $\begin{array}{c}\mathscr{D} \\
\stackrel{2}{0} \\
0 \\
0\end{array}$ & $\begin{array}{l}\mathscr{\infty} \\
\mathscr{2} \\
\infty \\
0 \\
0\end{array}$ & \begin{tabular}{c}
8 \\
8 \\
\hdashline \\
-1
\end{tabular} & $\mid \begin{array}{c}8 \\
8 \\
-i \\
-i\end{array}$ & 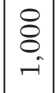 & $\mid \begin{array}{l}8 \\
\vdots \\
-1 \\
-1\end{array}$ & $\left|\begin{array}{l}8 \\
8 \\
-i\end{array}\right|$ & 8 & क् \\
\hline 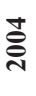 & $\begin{array}{l}\stackrel{H}{N} \\
\infty \\
0 \\
0\end{array}$ & $\begin{array}{l}8 \\
8 \\
- \\
-1\end{array}$ & $\begin{array}{l}8 \\
8 \\
-\end{array}$ & $\begin{array}{l}8 \\
8 \\
-i\end{array}$ & $\begin{array}{l}8 \\
8 \\
-1\end{array}$ & 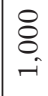 & $\begin{array}{l}8 \\
\stackrel{-}{-1}\end{array}$ & $\mid$\begin{tabular}{l|}
20 \\
$\mathscr{2}$ \\
0 \\
0
\end{tabular} & 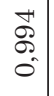 & $\begin{array}{c}8 \\
8 \\
-1\end{array}$ & $\begin{array}{c}8 \\
\vdots \\
-i\end{array}$ & $\mid \begin{array}{l}8 \\
8 \\
- \\
-1\end{array}$ & $\mid \begin{array}{l}8 \\
8 \\
- \\
-1\end{array}$ & $\left|\begin{array}{l}8 \\
8 \\
0 \\
-1\end{array}\right|$ & 8 & 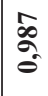 \\
\hline હิ̊ & $\begin{array}{l}8 \\
8 \\
-i\end{array}$ & $\begin{array}{l}8 \\
\& \\
-\end{array}$ & $\begin{array}{l}0 \\
\infty \\
\stackrel{0}{0} \\
0\end{array}$ & $\begin{array}{l}8 \\
8 \\
- \\
-1\end{array}$ & $\begin{array}{l}\sigma \\
\sigma \\
\sigma \\
0\end{array}$ & $\begin{array}{l}8 \\
\vdots \\
-1\end{array}$ & $\left|\begin{array}{l}8 \\
8 \\
\hdashline \\
-i\end{array}\right|$ & $\mid \begin{array}{l}\infty \\
\infty \\
\infty \\
0\end{array}$ & 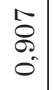 & $\mid \begin{array}{c}8 \\
8 \\
- \\
-1\end{array}$ & $\begin{array}{l}8 \\
8 \\
8 \\
-i\end{array}$ & $\mid \begin{array}{l}8 \\
8 \\
- \\
-1\end{array}$ & $\mid \begin{array}{l}8 \\
8 \\
0 \\
-1\end{array}$ & $\left|\begin{array}{l}8 \\
8 \\
-1\end{array}\right|$ & 8) & ஓू \\
\hline હิે & $\begin{array}{l}8 \\
8 \\
- \\
-\end{array}$ & $\begin{array}{l}8 \\
\varnothing \\
- \\
-1\end{array}$ & $\begin{array}{l}8 \\
8 \\
- \\
-1\end{array}$ & $\begin{array}{l}8 \\
8 \\
-1\end{array}$ & \begin{tabular}{l}
$\mathfrak{N}$ \\
\multirow{\infty}{\infty}{} \\
0 \\
0 \\
0
\end{tabular} & $\stackrel{8}{8}$ & $\begin{array}{l}-1 \\
\stackrel{8}{\circ} \\
0 \\
0\end{array}$ & $\mid \begin{array}{c}10 \\
5 \\
\sigma \\
0 \\
0\end{array}$ & 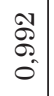 & \begin{tabular}{|l|}
0 \\
$\stackrel{2}{2}$ \\
$\stackrel{2}{0}$ \\
0 \\
\end{tabular} & $\mid \begin{array}{l}8 \\
8 \\
-i\end{array}$ & \begin{tabular}{|l|}
$\overrightarrow{5}$ \\
2 \\
0 \\
0 \\
0
\end{tabular} & $\begin{array}{l}8 \\
\vdots \\
-1 \\
-1\end{array}$ & $\left|\begin{array}{l}8 \\
8 \\
-i\end{array}\right|$ & 8 & 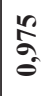 \\
\hline હ్亏 & \begin{tabular}{l}
8 \\
8 \\
\hdashline
\end{tabular} & $\begin{array}{c}8 \\
8 \\
- \\
-1\end{array}$ & $\begin{array}{l}8 \\
8 \\
-1\end{array}$ & $\begin{array}{l}8 \\
8 \\
-i\end{array}$ & $\begin{array}{l}-\overrightarrow{2} \\
\infty \\
0 \\
0\end{array}$ & $\stackrel{8}{8}$ & $\begin{array}{l}\mathcal{N} \\
\text { N } \\
\infty \\
0 \\
0\end{array}$ & $\begin{array}{l}0 \\
\& \\
8 \\
0\end{array}$ & $\begin{array}{c}8 \\
\vdots \\
-\end{array}$ & $\begin{array}{c}8 \\
\vdots \\
-1\end{array}$ & $\mid \begin{array}{c}8 \\
8 \\
-1\end{array}$ & 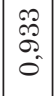 & $\mid \begin{array}{l}9 \\
\\
0 \\
0 \\
0\end{array}$ & $\left|\begin{array}{l}8 \\
8 \\
-1\end{array}\right|$ & $\stackrel{8}{8}$ & $\begin{array}{l}\hat{\alpha} \\
\sigma \\
\delta\end{array}$ \\
\hline હ્ડે & $\underset{8}{8}$ & $\begin{array}{c}8 \\
8 \\
-\end{array}$ & \begin{tabular}{l}
8 \\
8 \\
\hdashline \\
-1
\end{tabular} & $\begin{array}{c}8 \\
8 \\
-1\end{array}$ & $\begin{array}{l}\text { बे. } \\
\text { హ. } \\
0 \\
0\end{array}$ & $\stackrel{8}{8}$ & 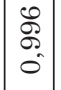 & $\begin{array}{l}0 \\
0 \\
0 \\
0 \\
0\end{array}$ & $\begin{array}{l}8 \\
ః \\
-\end{array}$ & $\begin{array}{l}8 \\
\vdots \\
-1\end{array}$ & $\begin{array}{l}8 \\
\searrow \\
-i\end{array}$ & $\mid \begin{array}{l}\mathbb{1} \\
\infty \\
0 \\
0 \\
0\end{array}$ & $\mid \begin{array}{l}8 \\
\vdots \\
-1\end{array}$ & $\left|\begin{array}{l}8 \\
8 \\
- \\
-1\end{array}\right|$ & $\begin{array}{l}8 \\
8 \\
0 \\
-1\end{array}$ & ڤू. \\
\hline 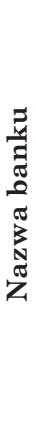 & 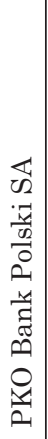 & 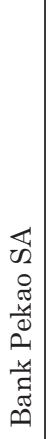 & 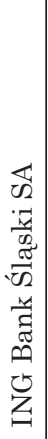 & 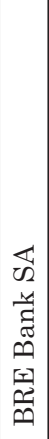 & 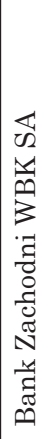 & 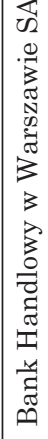 & 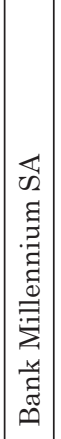 & 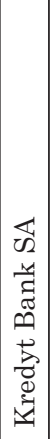 & 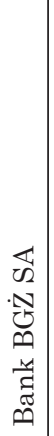 & 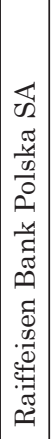 & 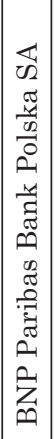 & 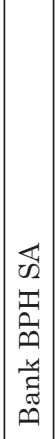 & 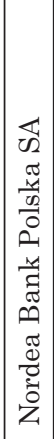 & 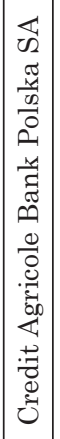 & 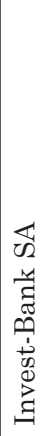 & 党 \\
\hline
\end{tabular}


- w sytuacji oceny zależności pomiędzy efektywnością techniczną a rentownością oszacowaną wskaźnikiem ROA - współczynnik korelacji liniowej Pearsona na poziomie 0,25 mówiący o słabej zależności dodatniej między cechami oraz wynik testu istotności współczynnika świadczący o braku podstaw do odrzucenia hipotezy zerowej o braku korelacji pomiędzy efektywnością a rentownością mierzoną wartością wskaźnika ROA badanych banków $(p$-wartość $=0,37)$.

\section{Tabela 4}

Liczba rentownych i nierentownych banków ze względu na wartość wskaźnika ROE w grupie banków efektywnych technicznie badanej zbiorowości w latach 2000-2012

\begin{tabular}{|l|c|c|c|c|c|c|c|c|c|c|c|c|c|}
\hline Typ banku & $\mathbf{2 0 0 0}$ & $\mathbf{2 0 0 1}$ & $\mathbf{2 0 0 2}$ & $\mathbf{2 0 0 3}$ & $\mathbf{2 0 0 4}$ & $\mathbf{2 0 0 5}$ & $\mathbf{2 0 0 6}$ & $\mathbf{2 0 0 7}$ & $\mathbf{2 0 0 8}$ & $\mathbf{2 0 0 9}$ & $\mathbf{2 0 1 0}$ & $\mathbf{2 0 1 1}$ & $\mathbf{2 0 1 2}$ \\
\hline \multicolumn{10}{|c|}{ banki efektywne } \\
\hline $\begin{array}{l}\text { banki } \\
\text { rentowne }\end{array}$ & 4 & 3 & 2 & 3 & 7 & 9 & 11 & 11 & 6 & 2 & 4 & 6 & 5 \\
\hline $\begin{array}{l}\text { banki } \\
\text { nierentowne }\end{array}$ & 7 & 7 & 7 & 7 & 5 & 3 & 2 & 2 & 6 & 10 & 10 & 8 & 6 \\
\hline \multicolumn{10}{|c|}{ banki nieefektywne } \\
\hline $\begin{array}{l}\text { banki } \\
\text { rentowne }\end{array}$ & 2 & 0 & 1 & 0 & 1 & 2 & 1 & 1 & 2 & 1 & 0 & 0 & 1 \\
\hline $\begin{array}{l}\text { banki } \\
\text { nierentowne }\end{array}$ & 2 & 5 & 5 & 4 & 2 & 1 & 1 & 1 & 1 & 2 & 1 & 1 & 3 \\
\hline
\end{tabular}

Źródło: opracowanie i obliczenia własne na podstawie danych z tabel 1 i 3.

\section{Tabela 5}

Liczba rentownych i nierentownych banków ze względu na wartość wskaźnika ROA w grupie banków efektywnych technicznie badanej zbiorowości w latach 2000-2012

\begin{tabular}{|l|c|c|c|c|c|c|c|c|c|c|c|c|c|}
\hline Typ banku & $\mathbf{2 0 0 0}$ & $\mathbf{2 0 0 1}$ & $\mathbf{2 0 0 2}$ & $\mathbf{2 0 0 3}$ & $\mathbf{2 0 0 4}$ & $\mathbf{2 0 0 5}$ & $\mathbf{2 0 0 6}$ & $\mathbf{2 0 0 7}$ & $\mathbf{2 0 0 8}$ & $\mathbf{2 0 0 9}$ & $\mathbf{2 0 1 0}$ & $\mathbf{2 0 1 1}$ & $\mathbf{2 0 1 2}$ \\
\hline \multicolumn{10}{|c|}{ banki efektywne } \\
\hline $\begin{array}{l}\text { banki } \\
\text { rentowne }\end{array}$ & 4 & 3 & 3 & 8 & 9 & 9 & 11 & 10 & 7 & 5 & 8 & 7 & 6 \\
\hline $\begin{array}{l}\text { banki } \\
\text { nierentowne }\end{array}$ & 7 & 7 & 6 & 3 & 3 & 3 & 2 & 3 & 5 & 7 & 6 & 7 & 5 \\
\hline \multicolumn{10}{|c|}{ banki nieefektywne } \\
\hline $\begin{array}{l}\text { banki } \\
\text { rentowne }\end{array}$ & 2 & 0 & 1 & 0 & 1 & 2 & 1 & 1 & 2 & 2 & 0 & 0 & 1 \\
\hline $\begin{array}{l}\text { banki } \\
\text { nierentowne }\end{array}$ & 2 & 5 & 5 & 4 & 2 & 1 & 1 & 1 & 1 & 1 & 1 & 1 & 3 \\
\hline
\end{tabular}

Źródło: opracowanie i obliczenia własne na podstawie danych z tabel 2 i 3. 
W celu poszerzenia wniosków odnoszących się do efektywności i rentowności banków tworzących próbę badawczą stworzono pewnego rodzaju mapę efektywności i zyskowności. Umożliwia ona identyfikację najlepszych podmiotów w grupie, charakteryzujących się zarówno wysokim poziomem efektywności, jak i zyskowności, stanowiących jednostki modelowe (benchmarki) dla pozostałych banków z próby badawczej ${ }^{37}$.

Koncepcję tę zaczerpnięto z idei metod portfelowych, których najpopularniejszym narzędziem analizy jest opracowana przez Boston Consulting Group macierz BCG, znana również jako macierz wzrostu/udziału w rynku. Podstawą tej metody jest analiza jednostek gospodarczych ze względu na wielkość udziału w rynku, wzrost rynku oraz zużycie/generowanie gotówki ${ }^{38}$.

Zmodyfikowana postać macierzy BCG umożliwia wyodrębnienie w grupie jednostek decyzyjnych poddanych analizie efektywności metodą DEA tzw. strategicznych obszarów biznesowych ze względu na uzyskany przez nie poziom efektywności technicznej oraz rentowności. Wyróżnić w ten sposób można grupy jednostek określanych mianem: „śpiochy”, „gwiazdy”, „psy” oraz „znaki zapytania”39. Ich rozmieszczenie w układzie współrzędnych, w którym wartości na osi poziomej obrazuja poziom efektywności, na osi pionowej zaś - poziom rentowności analizowanych podmiotów, przedstawiono na wykresie 1 .

\section{Wykres 1}

Postać macierzy BCG łącząca efektywność techniczną z rentownością podmiotów

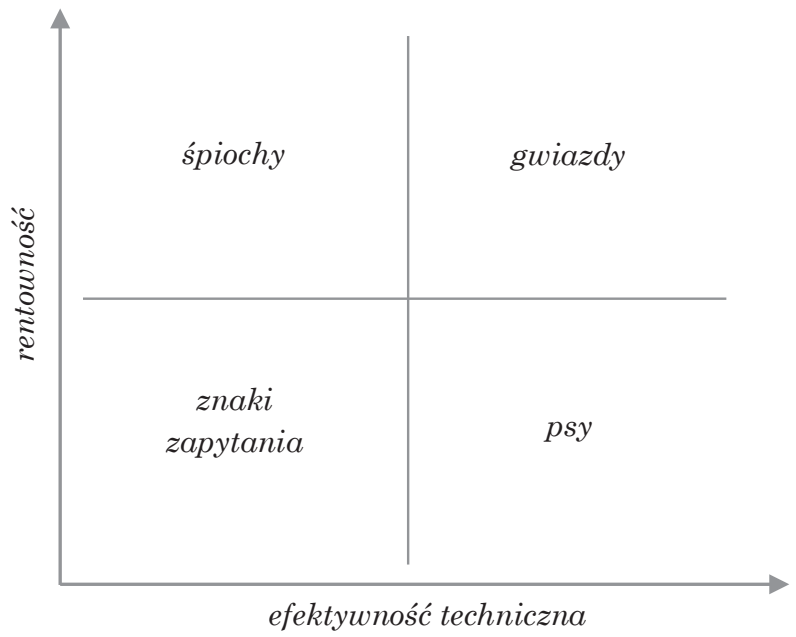

Źródło: M. Gospodarowicz, Procedury analizy..., s. 54.

${ }^{37}$ D. Sikora, A. Kulczycki, Efektywność oddziału banku detalicznego jako czynnik przewagi konkurencyjnej, CeDeWu, Warszawa 2008, s. 156.

38 J. A. E. Stoner, R. E. Freeman, D. R. Jr. Gilbert, Kierowanie, PWE, Warszawa 1999, s. 273 i 274 .

${ }^{39}$ M. Gospodarowicz, Procedury analizy..., s. 53 i 54. 
Zajmujące prawy - górny narożnik macierzy jednostki określane mianem „gwiazd" stanowią wzorzec dla pozostałych obiektów z uwagi na znakomita strategię finansową (uwidocznioną w wysokim poziomie rentowności) oraz poziom efektywności. Rentowne, lecz niewykorzystujące w pełni swoich zasobów (i stąd też wykazujące pewien stopień nieefektywności) sąjednostki w grupie „,́piochów”. „Znaki zapytania” to podmioty, w przypadku których właściwa strategia rozwoju może zaowocować wzrostem efektywności technicznej.

„Psy” mają przed sobą perspektywę wypadnięcia z rynku z racji wyjątkowo niskiej rentowności, której nie może zrekompensować nawet znaczący poziom efektywności ${ }^{40}$. Celem każdej przedstawionej w formie zmodyfikowanej macierzy BCG („mapy efektywności-zyskowności”) instytucji powinno być przesunięcie się w kierunku obszaru wyodrębnionego na północnym wschodzie, czyli w kierunku osiagnięcia parametrów efektywności i rentowości zbliżonych do grupy wzorcowej - jednostek typu „gwiazdy”.

Ilustrację map efektywności-zyskowności dla banków poddanych w niniejszej pracy analizie efektywności z wykorzystaniem metody DEA zaprezentowano na wykresach 2 i 3 . Pierwszy z nich dotyczy wyodrębnienia strategicznych obszarów biznesowych ze względu na poziom efektywności technicznej oraz wartość stopy zwrotu z kapitału własnego tworzacych zbiorowość badawczą banków. Drugi wiąże miarę efektywności technicznej z poziomem zwrotu na aktywach.

Wykres 2

Strategiczne obszary biznesowe banków wyróżnione ze względu na poziom efektywności technicznej oraz stopę zwrotu z kapitału własnego

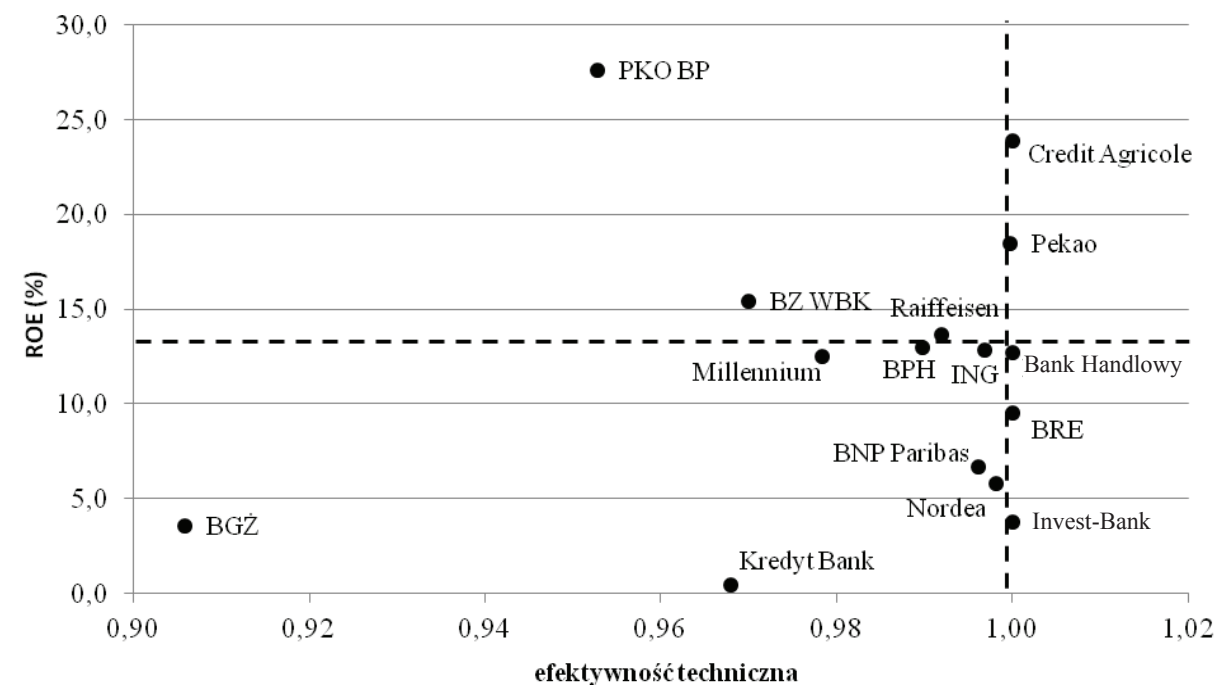

Źródło: jak w tabeli 1.

${ }^{40}$ Ibidem, s. 54. 
Wykresy 2 i 3 powstały na podstawie średnich miar efektywności i rentowności oszacowanych dla każdego analizowanego banku za lata 2000-2012. Linie odgraniczające poszczególne obszary ustalono, biorąc pod uwagę wskazane w punkcie 4 wartości graniczne dotyczące zyskowności oraz kryterium efektywności technicznej (efektywne są jednostki, których miara efektywności technicznej ecrs przyjmuje wartość 1).

Jak można zaobserwować na wykresach 2 i 3, grupę wzorcowych banków zaliczanych do grona „gwiazd” z uwagi na rentowność i efektywność techniczną w obu przypadkach wyznaczaja takie banki, jak: Bank Pekao SA i Credit Agricole Bank Polska SA. W przypadku powiązania poziomu efektywności z wartością wskaźnika ROA do grupy tej dodatkowo należy Bank Handlowy w Warszawie SA (w drugiej sytuacji zakwalifikowany jako „psy”).

Bankami, które bez względu na przyjętą miarę zyskowności charakteryzują się wyjątkowo niską rentownością i należą do grupy zagrożonej wypadnięciem z rynku jednostek, czyli do grupy „psów”, są BRE Bank SA i Invest-Bank SA.

Wykres 3

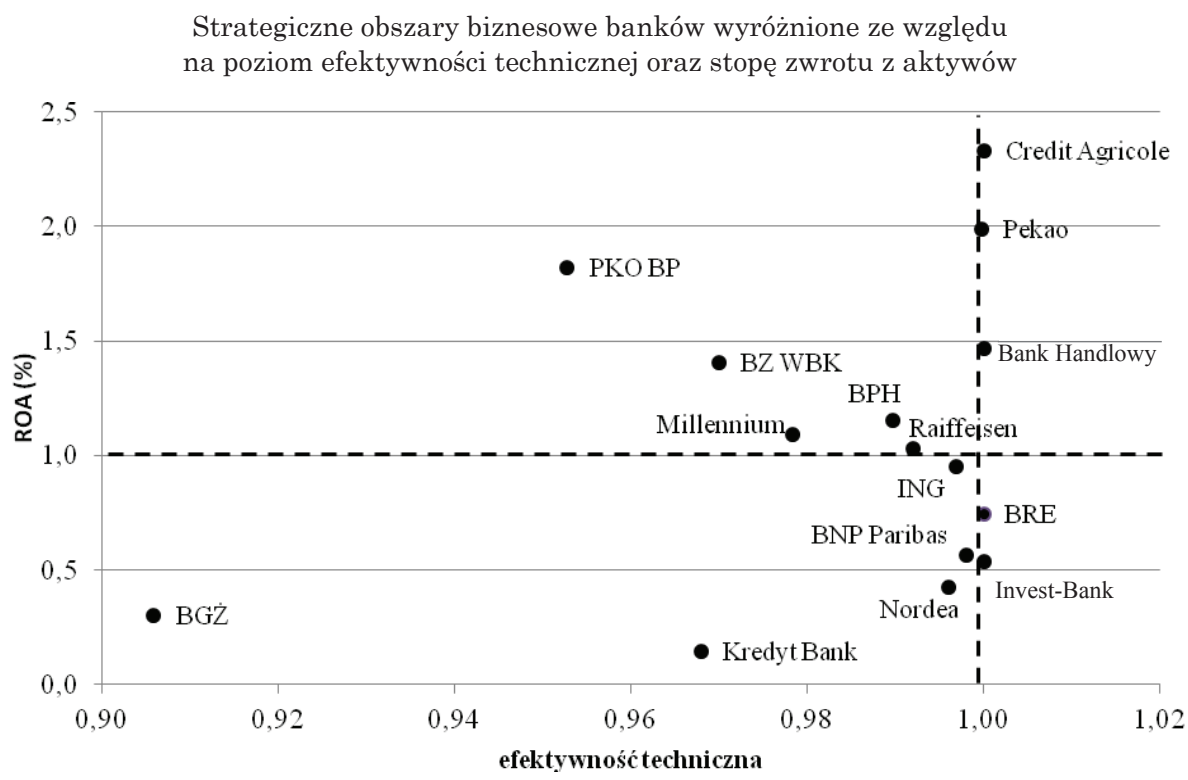

Źródło: jak w tabeli 1.

Bank BGŻ SA, Kredyt Bank SA, Nordea Bank Polska SA, BNP Paribas Bank Polska SA i ING Bank Śląski SA to przedstawiciele „znaków zapytania”, czyli banków, którym zmiana strategii rozwoju warunkuje wzrost efektywności. Biorąc pod uwagę związek efektywności technicznej z rentownościa kapitałów własnych, w takiej samej sytuacji dodatkowo znajduja się: Bank Millennium SA oraz Bank BPH SA (sklasyfikowane jako „śpiochy” ze względu na poziom efektywności i wskaźnika ROA). 
PKO Bank Polski SA, Raiffeisen Bank Polska SA oraz Bank Zachodni WBK SA to banki, które w obu klasyfikacjach są bankami rentownymi, a ich nieefektywność tłumaczona jest niepełnym wykorzystaniem dostępnych zasobów.

Występujące wśród badanych banków różnice w poziomie efektywności technicznej oraz rentowności (mierzonej wskaźnikami ROE/ROA) wynikaja przede wszystkim z odmiennej skali i sposobu finansowania prowadzonej przez nie działalności kredytowej. Dodatkowym czynnikiem determinującym poziom efektywności banków w okresie objętym analizą były zachodzące w ramach sektora bankowego przekształcenia własnościowe skutkujace wzrostem liczby banków z przewagą kapitału zagranicznego.

mgr Andizelika Redecka

Uniwersytet Ekonomiczny w Poznaniu

angelika.redecka@ue.poznan.pl

\title{
THE RELATIONSHIP BETWEEN EFFICIENCY AND PROFITABILITY OF POLISH COMMERCIAL BANKS
}

\author{
Sum mary
}

Assessment of a bank's efficiency may be performed in many areas: organisational, financial or cost. The article is an attempt to review the efficiency of Polish banking industry and the potential link between profitability and efficiency of Polish commercial banks operating in Poland between 2000 and 2012.

The important role of profitability indicators in business assessment is described, and the ROE and ROA indicators and their relationship to each other analysed. A division is then made into profitable and unprofitable banks based of their ROE and ROA indicator levels.

Next the Data Envelopment Analysis (DEA), a nonparametric method of measuring productive efficiency, is presented. Using the DEA method, the technical efficiency measures for the analysed banks were calculated. In the group of 15 banks, only four proved efficient throughout the analysed period.

The review performed based on the Pearson correlation coefficient has shown a very weak (for ROE) and a weak positive correlation (for ROA) between the profitability level and the efficiency of the banks. The coefficient significance test has shown, in both cases, that a null hypothesis regarding lack of relationship between the analysed properties cannot be rejected.

Using a modified BCG matrix, the banks of highest average efficiency and profitability have been identified. 
Copyright of Journal of Law, Economics and Sociology is the property of Faculty of Law and Administration of Adam Mickiewicz University in Poznan and its content may not be copied or emailed to multiple sites or posted to a listserv without the copyright holder's express written permission. However, users may print, download, or email articles for individual use.

Właścicielem praw autorskich do „Ruchu Prawniczego, Ekonomicznego i Socjologicznego” jest Wydział Prawa i Administracji Uniwersytetu im. Adama Mickiewicza w Poznaniu. Zawartość czasopisma nie może być kopiowana, przesyłana do innych stron internetowych bądź zamieszczana na blogach bez pisemnej zgody wydawcy. Niemniej artykuły można drukować, kopiować lub przesyłać w formie elektronicznej na własny użytek. 